\title{
Presence of Transcarboxylase in Arachnia Propionica
}

\author{
S. H. GEORGE ALLEN AND BARBARA A. LINEHAN \\ Department of Biochemistry, Albany Medical College, Albany, New York 12208
}

\begin{abstract}
Methylmalonyl-coenzyme A transcarboxylase is present in extracts of the four strains of Arachnia propionica tested. Four other enzymes involved in propionate production by the propionibacteria are also present.
\end{abstract}

The genus Arachnia (7) contains only one species, Arachnia propionica. Although classified with the actinomycetes because of its filamentous growth, biochemically it resembles the propionic acid bacteria. Cell walls of $A$. propionica, unlike the actinomycetes, contain diaminopimelic acid as do those of the propionic acid bacteria. The fermentation of glucose by A. propionica yields mainly propionate, acetate, and $\mathrm{CO}_{2}(6)$. This paper presents evidence that transcarboxylase (methylmalonyl-coenzyme A pyruvate carboxyltransferase, EC 2.1.3.1), which was previously found only in bacteria of the genus Propionibacterium, is also present in A. propionica.

A. propionica type strain ATCC 14157 was obtained from the American Type Culture Collection, Rockville, Md. Strains 427, 346, and 439 were the gift of Mary Ann Gerencser of the University of West Virginia, Morgantown, W. Va. A. propionica was grown either on actinomyces broth (Difco) or on liquid medium no. 10 of Caldwell and Bryant (2). Cultures were grown under strict anaerobic conditions in an atmosphere of $100 \% \mathrm{CO}_{2}$ in serum bottles as described by Miller and Wolin $(5)$ at $37^{\circ} \mathrm{C}$. Addition of Tween 80 at a final concentration of $0.1 \%$ was found to enhance growth. Cell-free extracts were prepared by sonic extraction, and protein was determined using the microbiuret method (3).

The transcarboxylase was assayed by follow- ing the rate of oxalacetate production by using either the direct spectrophotometric (9) or a two-step assay (8) with malate dehydrogenase. Lactate and malate dehydrogenases were assayed with reduced nicotinamide adenine dinucleotide using standard procedures. Acetate kinase and coenzyme A transferase were assayed as described by Allen et al. (1). Fumarase was assayed at $300 \mathrm{~nm}$ (4).

Table 1 presents the specific activities of some of the enzymes important in fermentation by Propionibacterium shermanii. All of these activities are present in extracts of $A$. propionica. Most importantly, the transcarboxylase is found in the four strains tested at specific activities comparable with those found in the propionibacteria. Extracts of A. propionica contained little or no lactate dehydrogenase so that the direct spectrophotometric assay for transcarboxylase could be done on the crude extracts. Malate dehydrogenase, fumarase, and acetate kinase all had activities comparable to those found in the propionibacteria. The acetate kinase, like that of $P$. shermanii, was found to have almost equal activity with propionate as substrate, whereas the acetate kinase of Escherichia coli has about $2 \%$ of its maximal activity on propionate. The coenzyme A transferase was not as active in extracts of $A$. propionica as that found in $P$. shermanii, but was nevertheless present. On the basis of these activities, as well as the similarities in fermentation products (6),

TABLE 1. Specific activities of some enzymes involved in propionate production

\begin{tabular}{cccccc}
\hline Organism & $\begin{array}{c}\text { Transcarboxyl- } \\
\text { ase }\left(\mathrm{U} / \mathrm{mg}^{a}\right)\end{array}$ & $\begin{array}{c}\text { Malate dehydro- } \\
\text { genase }\left(\mathrm{U} / \mathrm{mg}^{a}\right)\end{array}$ & $\begin{array}{c}\text { Fumarase }(\mathrm{U} / \\
\left.\mathrm{mg}^{a}\right)\end{array}$ & $\begin{array}{c}\text { Acetate kinase } \\
\left(\mathrm{U} / \mathrm{mg}^{a}\right)\end{array}$ & $\begin{array}{c}\text { Coenzyme A } \\
\text { transferase }(\mathrm{U} / \\
\left.\mathrm{mg}^{a}\right)\end{array}$ \\
\hline $\begin{array}{c}\text { Propionibacterium } \\
\text { shermanii }\end{array}$ & 0.45 & $22^{b}$ & $4.6^{c}$ & $0.86^{b}$ & $1.31^{b}$ \\
$\begin{array}{c}\text { Arachnia propionica } \\
\text { ATCC 14157 }\end{array}$ & 0.18 & & & & \\
WVU 427 & 0.36 & 4.3 & 6.5 & & 0.03 \\
WVU 346 & 0.37 & & & & \\
WVU 439 & 0.15 & & & & \\
\hline
\end{tabular}

a Micromoles of product formed per minute per milligram of protein.

${ }^{b}$ Specific activities as reported by Allen et al. (8).

c Unpublished data, S. H. G. Allen. 


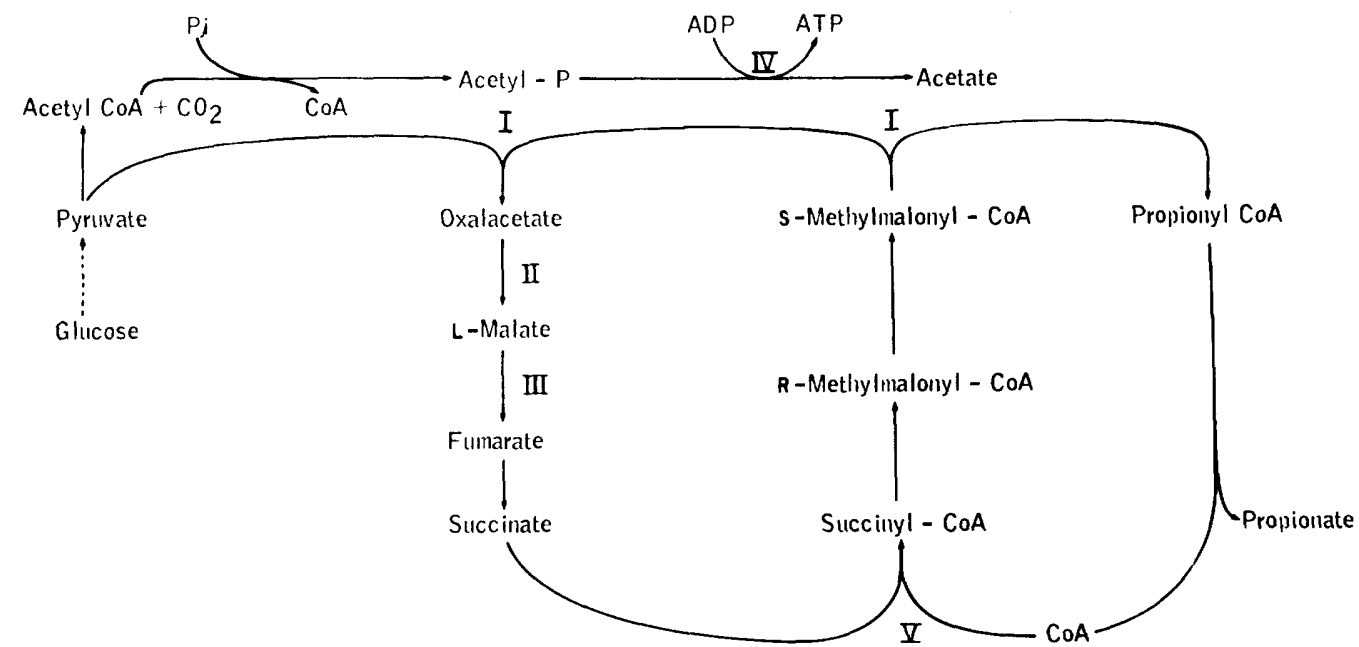

Fig. 1. Proposed fermentation scheme for Arachnia propionica. Starting with glucose, the dotted line to pyruvate indicates glycolysis. Roman numerals indicate the enzymes present in A. propionica: (I) transcarboxylase; (II) malate dehydrogenase; (III) fumarase; (IV) acetate kinase; (V) coenzyme A transferase. The other enzymes are represented by analogy with the fermentation scheme of $P$. shermanii (1).

it appears that $A$. propionica utilizes the same pathway for propionate production as the propionibacteria (Fig. 1). From a taxonomic point of view the most interesting observation is the presence in A. propionica of transcarboxylase which has been found only in propionibacteria. This fact, together with the other similarities, reinforces the argument that $A$. propion$i c a$ should be transferred to the genus Propionibacterium as suggested by Pine (6).

This research was supported by Public Health Service grant DE 4284 from the National Institute of Dental Research.

\section{REPRINT REQUESTS}

Address reprint requests to: Dr. S. H. George Allen, Department of Biochemistry, Albany Medical College, Albany, NY 12208.

\section{LITERATURE CITED}

1. Allen, S. H. G., R. W. Kellermeyer, R. L. Stjernholm, and H. G. Wood. 1964. Purification and properties of enzymes involved in the propionic acid fermentation.

\section{J. Bacteriol. 87:171-187.}

2. Caldwell, D. R., and M. P. Bryant. 1966. Medium without rumen fluid for nonselective enumeration and isolation of rumen bacteria. Appl. Microbiol. 14:794801.

3. Itzhaki, R. F., and D. M. Gill. 1964. A microbiuret method for estimating proteins. Anal. Biochem. 9:401-410.

4. Massey, V. 1955. Fumarase. Methods Enzymol. 1:729735.

5. Miller, T. L., and M. J. Wolin. 1974. A serum bottle modification of the Hungate technique for cultivating obligate anaerobes. Appl. Microbiol. 27:985-987.

6. Pine, L. 1970. Classification and phylogenetic relationship of microaerophilic actinomycetes. Int. J. Syst. Bacteriol. 20:445-474.

7. Pine, L., and L. K. George. 1969. Reclassification of Actinomyces propionicus. Int. J. Syst. Bacteriol. 19:267-272.

8. Stjernholm, R., and H. G. Wood. 1961. Transcarboxylase. II. Purification and properties of methylmalonyl-oxaloacetic transcarboxylase. Proc. Natl. Acad. Sci. U.S.A. 47:289-303.

9. Wood, H. G., B. Jacobson, B. I. Gerwin, and D. B. Northrop. 1969. Oxaloacetate transcarboxylase from Propionibacterium. Methods Enzymol. 13:215-230. 